\title{
VOICES FROM THE NINETEENTH-CENTURY: WOMEN TRAVELERS AND POLITICAL ACTIVISM
}

\author{
Juraci Andrade de 01iveira Leão*
}

ABSTRACT :

This study aims at analyzing some aspects in the diaries: Journal of a Voyage to Brazil, by the British Maria Graham, and Peregrinations of a Pariah, by the FrenchPeruvian Flora Tristan. This essay discusses how these women travelers transgressed the role ascribed to them in society through their intervention in the political sphere and how such aspects contribute to the construction of a new female identity.

KEY WORDS: travel writing, women travelers, female identity.

Literature has performed an important role in the representation of the condition of women in society, mainly because this condition is partially constructed through discourse. Among other genres, travel writing by women called my attention due to the fact that the authors tried to present their texts as a personal, nonmediated, and spontaneous way of telling a story; however, these narratives also present a fictional dimension. Women had to fit their texts to social expectations in order to have them published; thus, there was an intentionality that mediated the supposed spontaneity of discourse.

Unlike the writers of fictional works, most of the time these women travelers explicitly reveal details of their private experiences through their writings. In this sense, they are breaking the so-called "frontiers" between the public and the private. Furthermore, they undermine their traditional location in * Mestre em Letras: Estudos Literários (Área de concentração: Literaturas de Expressão Inglesa), 2001. 


\section{EMTESE}

Belo Horizonte, v. 6, p. I-253, ago. 2003

the private sphere from the moment they leave their homes in order to travel. In this way, the voyage and also the writing become transgressive in terms of the restrictions socially imposed on women. Their writings reflect, to a large extent, the ideology of imperialism, colonization, and male superiority. It seems necessary then to analyze the function of the voyage during the nineteenth century as part of the civilizing mission and expansion of the European culture, mainly because women travelers also fulfilled a social role when traveling. If, towards the beginning of the nineteenth century, women from the middle class had already extended their domestic function of teaching and nursing to the public sphere in their own country, they would also transpose this social duty to the country they visited. While this social work was related to class values in their countries, in the new land it was related not only to class but to national values as well. Women travelers reveal their commitment to the civilizing perspective not only by accepting this social duty to fulfill but also as they transform it in political practice through their writings. Women acquire a certain authority which unbalances their subordinate social position. If, as women, they are considered secondary in terms of power in their society, as white European women, they are going to be a more empowered subject in the country they visited. They are in an ambiguous position; as Gazzola has stated in "Mulheres à Deriva" they are at the same time peripheral and central.

The dislocation from the place reserved for women (that is, inside the house) gives them the opportunity to observe other cultures and establish comparisons with their own conditions. The women travelers start to circulate in the public sphere, expanding their space in society and presenting a shift in their roles which threatens male control, as Mary Suzanne Schriber points out: "They seemed not simply to transgress the borders of woman's sphere but to usurp the role of men". (Schriber, 1997: 42). We notice that their task was not only to broaden their space in society, but also to negotiate a new identity. The notion of individuality was only applied to men, in the sense that the subject position was guaranteed for them. Women were, rather, objects of discourse. That is why writing is important for these women, since it allows them to construct a subject position for themselves. Their writing becomes sometimes dislocated and slippery, especially if we consider that men were the ones who could take on a public position. In this way, "to become an individual" 
for those women meant to construct themselves as feminine, differentiated from the male identity. However, because masculinity is what guarantees the public position, they must negotiate and acquire certain masculine characteristics, without losing the feminine ones, which they reinforced repeatedly. That is why women's discourse is slippery, since it embodies those various aspects, which provoke an oscillation in the subject position.

Bearing all these aspects in mind, I chose to work with women who symbolize this moment of the feminine discourse of traveling. And because they had a remarkable participation in politics, these women's narratives present contradictions in their subject positions. Even when there was no political action during the journey, we perceive through their voices that they defend traces of an agency that they would develop further. Hence, it is important to analyze how those elements contributed to the construction of a new female identity through the writers' intervention in the public sphere reflected in their writings.

Among the women travelers who visited South American countries and wrote about their experiences there I chose to work with the British Maria Graham and the French-Peruvian Flora Tristan. Graham not only wrote about Brazilian culture but she also witnessed and occasionally acted in the Brazilian political scenery. Tristan visited Peru one decade after Graham's stay in Brazil, and she observed important moments of the Peruvian history. This author registered her experience in Peru, and, although her political participation in Peru had been less explicit than Graham's, Tristan got involved in the Peruvian political arena, too. And if we consider that by the time of their travels, both countries were struggling to consolidate their independence, we will perceive that both Graham and Tristan not only witnessed important political events in those countries, but they also interfered in such processes.

A brief insight into the life of a nineteenth-century woman in French society becomes necessary to understand the ambivalence of Tristan's narrative. The ambiguous social advances resulting from the French Revolution and the subsequent repression of women imposed by Napoleon had certainly influenced the trajectory of the French-Peruvian Flora Tristan. Differently from Graham, this woman traveled to Peru in search of her family roots as well as to claim her inheritance. Tristan's 


\section{EM TESE}

Belo Horizonte, v. 6, p. I-253, ago. 2003

objectives were not met in terms of being recognized as a legitimate member of her family, however, this trip seems to be the starting point for her trajectory as a writer and, later on, as a political activist. And although her other works might reveal more clearly Tristan's political activism, the object of my analysis will be her diary Peregrinations of a Pariah, which describes her journey to Peru. Tristan's narrative follows literary conventions of that time in that, similar to her European contemporary travel writers, she also reveals her feelings of superiority over the natives. However, Tristan seems to be more committed to the less privileged people in society, which is revealed in her discussions of the conditions of slaves and women. Tristan seems to identify with those people as she reflects about their situation. Tristan's narrative also presents some ambiguities, particularly in relation to her search for identity. She sees in her journey to Peru the chance to restore her lost social status; as this fails, she demonstrates her feeling of inbetweeness.

The Journal of a Voyage to Brazil, and Residence there, During Part of the Years 1821, 1822, 1823, by the British writer Maria Graham, also reveals traces of the women's condition in the nineteenth century. In this diary, Graham registered important facts of Brazilian history presented from a feminine viewpoint by interpreting them through her comments. Moreover, not only did Graham write about Brazilian political issues, but she also revealed her courage and self-confidence by mediating social conflicts during the time she stayed in Pernambuco. As the author portrayed the Brazilian social reality of that time, she demonstrated her commitment to the imperialist ideal. Her constant references to Brazilian culture as inferior as well as the observations she presents of women and slavery confirm her perspective as an outsider. She did not demonstrate any identification with the people; on the contrary, Graham's contact with Brazilian culture reinforced the value of the European pattern and confirmed her feeling of superiority over this "new" culture.

These two writers, Maria Graham and Flora Tristan, transgressed rules of a patriarchal society by ignoring the domestic role ascribed to them and venturing themselves in the outside world. They transgressed not only through their travels and insertion in the literary field, but also as they became acting subjects in the political sphere which was, at that time, specifically masculine. Despite the 
fact that they were apparently partaking of the view of European expansionism through their discourse of the civilizing mission, these women were also fulfilling an important role in the history of women. Thus, they were contributing to broadening frontiers and enlarging women's place in society.

By traveling abroad, these women freed themselves from domestic constraints while at the same time they constructed their new identities. The travel catalyzed a restructuring of these women's lives, as Gazzola has pointed out: "toda viagem envolve um remapeamento, uma re-locação de fronteiras, uma negociação entre a casa e o lugar distante, entre a própria cultura e a cultura outra. A viagem, assim como a escrita, representam para a mulher uma forma de dissidência". (Gazzola, 1995: 79). The experience of displacement enabled the writers to have a different view of their condition in society from the moment they left their countries and established contact with a new culture.

Both Tristan and Graham faced difficult situations abroad, mainly because the countries they visited countries, Brazil and Peru, were still struggling to consolidate their independence. Thus, these women witnessed constant military upheavals during which they ran the risk of being attacked, even considering the fact they were viewed as outsiders in those countries. Moreover, both Graham and Tristan demonstrated through their narratives that they did not remain far from those processes; on the contrary, they got involved in them as both travelers negotiated and inserted their point of view in the political context of these countries. While Graham mediated the conflict in Pernambuco by persuading the governor to give up his plans, Tristan advised her uncle and his allies on the political strategies to be used during the military conflicts in Arequipa. In this way, Tristan and Graham's entrance in the public sphere was not only marked by their travels, but also by their transit in the political field.

Both authors used several strategies to legitimate their discourse and assume a subject position. Maria Graham established intertextuality with some European male writers (philosophers, poets and dramatists), while Tristan made use of her own family status. Graham exalted European values and reduced the ones of the visited country. Tristan, although less assertive than Graham, al so elevated European 


\section{EMTESE}

Belo Horizonte, v. 6, p. I-253, ago. 2003

culture, but she indicated its failures, too. Tristan, differently from Graham, recognized the authoritative system of her civilization. By observing women's condition in Peru, Tristan not only certified their submissive role in society, but she also identified with them. Graham, on the other hand, always established a cultural gap between her and the native women.

We perceive in both narratives a concern with economic and political interests. Graham's observation of the new land revealed a certain commitment to the imperialist ideal as she reinforced the need of the European presence in order to civilize Brazil. Politics and power were the main issues in Graham's narrative. She attached to her narrative long speeches of the Emperor and presented her own comments about the events and intrigues in the Brazilian court. Tristan also contextualized the Peruvian political moment, but she presented a deeper analysis of the social questions she observed. While Graham reaffirmed the instituted power, Tristan criticized the foundations which supported that power. In this sense, Graham made the events of the Brazilian court the focus of her narrative whereas Tristan concentrated on describing and attacking the values of a discriminatory society.

Thus, Tristan's diary presents her sympathy for the subaltern people in society. She was interested in transforming not only women's condition but the slaves' as well. She seemed to be shocked with the treatment of slaves in Peruvian society, and to a certain extent she tried to identify with them. She classified slavery as a retrograde form of work and we notice her attempt to fight for a change in the slaves' social condition. Graham also criticized the way slaves were treated, but she concentrated on the backwardness of the country to organize its society. Her observation towards slaves reveals her superficial view of their condition.

Education was also very important for both travel writers, as Graham and Tristan viewed people's intellectual formation as a way to reach a higher level of civilization. Graham reinforced the value of education, although she disbelieved in an effective educational process in Brazil in a short period of time. She revealed her commitment to education through her tireless search for knowledge, which is reflected in her narrative. Therefore, such concern seems to be more connected with 
her personal improvement, whereas in Tristan's narrative the question of education seems to assume a universal dimension. Tristan expressed the necessity of education in order to improve people's social condition.

As women travelers were away from home, separated from the place and people they loved, they discovered themselves. They also discovered and learned to value their countries of origin. Women's distance from home seems to increase their sense of nationalism. According to Schriber, "Travel appears to develop if not give birth to the nationalistic sentiments that characterize women's travel writing across the century" (1997: 104). This characteristic is more clear in Graham's narrative. She declared that the news from England would restore her strength and always reasserted her feelings as a European. Flora Tristan, on the other hand, oscillated in relation to her own nationality: She had already felt excluded from French society and would feel twice excluded in Peru. Her relatives' refusal to recognize her as a legitimate member of the family as well as her difficulties to adapt to their culture brought about her return to France. Before her journey to Peru Tristan had already felt an outcast in society. Her experience in Peru only reinforced her sense of in-betweeness.

In both diaries there are evidences that Graham and Tristan's involvement in public questions replaced feelings of sorrow and awakened them to other concerns. The political activism of Maria Graham was an instrument to participate in the center of decision. She empowered herself as a woman through her involvement with the Brazilian court. This empowerment would result later in the opportunity of working as the governess of the princess Maria da Glória. Similarly, the experience Tristan acquired during the travel had as a result a view of a political activism, to which she would dedicate herself later. Tristan returned to France and engaged herself in becoming the representative of the others, choosing the role of the one who would provide them with empowerment. Hence, both writers played important roles in their political lives. However their intervention differed, as Graham emphasized the individual dimension whereas Tristan concentrated her efforts on the collective perspective. Although in different levels and limited by the constraints of their origin, social condition and views, both Tristan and Graham embody the female figure from the nineteenth century, whom Hobsbawn and Henry James called the New woman. 


\section{EM TESE}

Belo Horizonte, v. 6, p. I-253, ago. 2003

RESUMO:

Esse ensaio analisa alguns aspectos presentes nos diários Journal of a Voyage to Brazil, da inglesa Maria Graham, $e$ Peregrinations of a Pariah, da francesa-peruana Flora Tristan. 0 texto discute como essas viajantes transgrediram o papel tradicionalmente reservado às mulheres por meio de incursões na esfera da política, contribuindo para a construção de uma nova identidade feminina.

PALAVRAS-CHAVE: literatura de viagem, mulheres viajantes, identidade feminina.

\section{REFERENCES}

GAZZOLA, Ana Lúcia Almeida. Mulheres à Deriva: Viajantes Anglo-Americanas no Brasil. Cadernos de Pesquisa. NAPq, 1995 .

GRAHAM, Maria. "Correspondência entre Maria Graham e a Imperatriz Dona Leolpoldina". Rio de Janeiro: Biblioteca Nacional do Rio de Janeiro. Serviço gráfico do Ministério da Educação e Saúde, 1940.

- Diário de Uma Viagem ao Brasil. Trad. A.J.L. Belo Horizonte: Itatiaia, 1990.

- Journal of a Voyage to Brazil, and Residence there during parts of the Years 1821, 1822, 1823. London: Longman, Hurst, Rees, Orme and Brown, 1824.

HOBSBAWN, Eric J. "A Nova Mulher". In: Hobsbawn, Eric J. A Era dos Impérios 1875 - 1914. Trad. Sieni Maria Campos, Yolanda Steidel de Toledo. Rio de Janeiro: Editora Paz e Terra, 1989.

SAID, Edward W. Culture and Imperialism. New York: Vintage, 1994.

SCHRIBER, Mary Suzanne. Writing Home: American Women Abroad 1830 - 1920. United States of America: The University Press of Virginia, 1997. 